Katarzyna Olbrycht*

Cieszyn

\title{
Wartość służby w wychowaniu chrześcijańskim - w świetle refleksji Jana Pawła II i Benedykta XVI
}

Centrum zarówno teoretycznych programów wychowawczych, jak praktyki wychowawczej stanowią wartości. Wyznaczają one cele, zadania, zasady, ramy stosowanych metod i środków, budują etos wychowawców, wpływają na treści przekazów wychowawczych.

Myślenie o wychowaniu w perspektywie wartości obejmuje wybór tych, które mają ukierunkowywać cały proces wychowania, ale i tych, które mają być $\mathrm{w}$ tymże procesie realizowane, urzeczywistniane. Wychowanie tak do wartości wyznaczających kierunek działań wychowawczych, jak i do wartości, które powinny zostać w tych działaniach uwzględnione jako szczególnie ważne, jest procesem złożonym. Oznacza bowiem uświadamianie ich sensu i znaczenia, kształcenie postaw i zachowań, które, służąc wartościom kierunkującym, same stają się wartościami, ukazywanie przykładów ich realizacji, wreszcie stwarzanie warunków do ich doświadczania i praktycznego urzeczywistniania.

Jedną z wartości niezwykle ważnych dla rozwoju człowieka i społeczeństwa, a niezbędnych w rozwoju osobowym i chrześcijańskim, jest ,,służ-

* Prof. zw. dr hab. Katarzyna Olbrycht jest kierownikiem Zakładu Edukacji Kulturalnej na Wydziale Etnologii i Nauk o Edukacji Uniwersytetu Śląskiego w Cieszynie. Adres: Uniwersytet Śląski, Cieszyn, Wydział Etnologii i Nauk o Edukacji, ul. Bielska 62, 43-400 Cieszyn; e-mail: k.olbrycht@onet.pl. 
ba". Służbę zarówno w sensie konkretnego działania, jak i w sensie postawy służby (jako rozumienia, akceptacji i gotowości do podejmowania służby), można równocześnie uznać za warunek życia wartościami. Odkryte i uznane wartości domagają się bowiem wierności i służby. Stąd obecność w języku metaforycznego określenia „służba wartościom”. W dzisiejszej kulturze i życiu społecznym służba i postawa służby są, jak się wydaje, zapoznane, społecznie marginalizowane, a w konsekwencji nieobecne także w myśleniu o wychowaniu, pomijane w działaniach pedagogicznych. Twórczość Aleksandra Kamińskiego, odnoszącego ideały służby i braterstwa do etosu harcerskiego, jest tu jednym $\mathrm{z}$ wyjątków ${ }^{1}$.

Jeśli uznać, że dla działań pedagogicznych ważne jest dostrzeżenie, że jakaś wartość znacząca społecznie i kulturowo, a tym samym wychowawczo, nie jest ceniona i urzeczywistniana, niezbędne staje się dokładniejsze rozpoznanie przyczyn i potencjalnych skutków tej sytuacji. W przypadku „służby” należałoby przyjrzeć się, w jaki sposób jest ona interpretowana i traktowana w dzisiejszej kulturze, szczególnie w wychowaniu chrześcijańskim, z którym jako postawa warunkująca realizację wartości osobowych i chrześcijańskich jest ściśle związana. Należałoby więc postawić kilka pytań: jaki jest stosunek dzisiejszej kultury do służby (jako postawy i działania) i czym jest uwarunkowany? Jakie jest miejsce służby w myśli o wychowaniu i praktyce wychowawczej? Czy w chrześcijaństwie służba może być oddzielana od wiary? Jakie są i mogą być konsekwencje takiego rozdzielania? Jakie zadania dla wychowania chrześcijańskiego wynikają z nastawienia współczesnego człowieka do służby? Wnikliwa odpowiedź na wszystkie te pytania przekraczałaby ramy artykułu. W przedstawianym tekście skoncentruję się na służbie widzianej w perspektywie wychowania chrześcijańskiego, zakładającego u podstaw wychowanie człowieka jako osoby.

Obserwacja życia społecznego prowadzi do wniosku, że „służba” jest w dzisiejszej kulturze nie tylko nieobecna, ale jest w niej traktowana jako w pewnym sensie kompromitująca, a nawet zagrażająca tym, którzy chcieliby ją podjąć, bowiem zaprzecza dominującemu systemowi wartości. $Z$ jednej strony, jest przeciwieństwem władzy (tym samym może być uznana za wyraz słabości) i interesowności (jej podstawą jest bezinteresowność oznaczająca naiwną rezygnację z orientacji na zysk), z drugiej - wydaje się być zagrożeniem dla wolności (służba historycznie łączyła się z utratą wolności), a także dla równości (służenie oznacza podleganie komuś, a więc niższy

${ }^{1}$ Krystyna Heska-Kwaśniewicz, Braterstwo i stużba. Rzecz o pisarstwie Aleksandra Kamińskiego (Katowice: Wydawnictwo Uniwersytetu Śląskiego, 1998). 
status). Niepopularność służby łączy się także z historycznymi konotacjami społecznymi. Sceptyczne nastawienie do służby pogłębia fakt, iż dla współczesnego człowieka ważnym motywatorem do aktywności i wysiłku jest osiąganie sukcesów. W tym kontekście, gdyby uznać „służbę” za zachowanie i postawę pozytywną, pożądaną, mogłoby to oznaczać rezygnację $\mathrm{z}$ dążenia do sukcesu.

Współczesna kultura, dystansując się do służby, jednocześnie zachowuje pewne obszary, w których podkreśla jej walory i traktuje jako wartość. Obszary te rezerwuje dla działalności szczególnie ważnej, odwołującej się do wysokich ideałów, najwyższych wartości, wymagającej ponadprzeciętnych cech charakteru (w tym odwagi), umiejętności i determinacji, zdolności, odpowiedzialności i gotowości do poświęceń. Dlatego utrzymuje ,służbę" w nazewnictwie takich zawodów i zajęć, jak: służba wojskowa, służba zdrowia, służby ratownicze, służby wartownicze itp.

Mały słownik języka polskiego podaje wiele znaczeń słowa „służba”, wymieniając między innymi:

- spełnianie posług, wykonywanie pracy służącego w czyimś domu, gospodarstwie za wynagrodzeniem; też: osoby wykonujące takie prace;

- pracę w urzędzie państwowym, pracę w instytucji użyteczności publicznej, wojsku itp.; też: pracowników tej instytucji;

- działalność tych instytucji;

- obowiązki pełnione w określonych godzinach pracy w niektórych instytucjach;

- bycie czyimś stronnikiem, działanie w czyimś interesie, zabieganie o czyjeś dobro, bycie zwolennikiem czegoś, np. jakiejś idei;

- służącego, sługi².

W efekcie wielości znaczeń rozumienie „służby” w dzisiejszej kulturze nie jest jednoznaczne. $Z$ jednej strony, nie jest uznawana za wartość dotyczącą życia pojedynczego człowieka, z drugiej - zachowuje się ją, jak wspomniano, dla postaw i działań specjalnych, wymagających ponadprzeciętnego wysiłku, zaangażowania, odpowiedzialności, ofiarności, zasługujących na szczególny szacunek.

Wśród podanych przez cytowany słownik znaczeń nie znajdujemy dwóch niezwykle ważnych dla myślenia pedagogicznego. Są to służba ważnym wartościom (i w podobnym sensie - służba „sprawie”) oraz służ-

2 Stanisław Skorupka, Halina Auderska, Zofia Łempicka, Mały słownikjęzyka polskiego (Warszawa: PWN, 1969), 757. 
ba Bogu. Można jednak przyjąć, że mieszczą się one w dwu ze znaczeń i związków frazeologicznych podanych w Stowniku frazeologicznym języka polskiego, gdzie pisze się o służbie „,czego i czemu (np. prawdzie sprawiedliwości)”, a także, że służba to „oddać się, poświęcić się służbie czego, lub czyjej (np. ojczyzny, społeczeństwa), pracować dla jakiejś idei, sprawy"”.

„Służba wartościom” jest sformułowaniem metaforycznym, stosowanym w odniesieniu do wartości najważniejszych dla człowieka (życie, człowiek, wolność, pokój), wartości osobowych, w tym duchowych (prawda, dobro, piękno) i kulturowych (ojczyzna, dziedzictwo kulturowe, tradycja). Odkrycie tych wartości powinno wywołać potrzebę odpowiedzenia na nie, oddania im sprawiedliwości, a prowadząc do przyjęcia ich jako powinności, wymaga wierności i służby. Służba wartościom oznacza gotowość ich ofiarnego urzeczywistniania, poprzez bezinteresowne w swojej istocie stwarzanie i utrwalanie warunków do ich ujawnienia się. W tym sensie służba jest łączona $\mathrm{z}$ „poświęcaniem się” jako bezinteresownym przekraczaniem niezbędnego minimum wysiłku i zaangażowania, określonych zakresem obowiązków, regułami, zewnętrzną kontrolą i formalnie egzekwowanych. Wychowawcze myślenie o „służbie” łączy to pojęcie ze służbą wartościom i temu, co uznaje się za szczególnie wartościowe.

Odrębne znaczenie niesie pojęcie „służby Bogu”. Obejmuje służbę Komuś Najwyższemu i w konsekwencji wszelkim wartościom, które z tej relacji wynikają a równocześnie ją pogłębiają.

Z perspektywy wiary chrześcijańskiej, a tym samym wychowania chrześcijańskiego, nie ma możliwości dystansowania się od „służby”; przeciwnie - im bardziej człowiek zbliża się do wiary, tym bardziej zbliża się do służby. Wychowanie chrześcijańskie mające wprowadzić w chrześcijaństwo, pomóc $\mathrm{w}$ budowaniu i pogłębianiu tożsamości chrześcijańskiej i rozwoju chrześcijańskich postaw, musi pokazać wartość i piękno służby drugiemu. Znamienne jest bardzo częste występowanie służby na kartach Pisma Świętego. Pojawia się w różnych kontekstach, od starotestamentalnego Cierpiącego Sługi Jahwe, czy deklaracji Samuela „mów Panie, bo sługa Twój słucha” (1 Sm 3, 10), aż do słów Maryi „oto ja służebnica Pańska” (Łk 1, 38), a przede wszystkim pouczenia Chrystusa: „Jeśli kto chce być pierwszym, niech będzie ostatnim ze wszystkich i sługą wszystkich!” (Mk 9, 35). W Biblii służba odnosi się przede wszystkim do służby Bogu, z której wynika służba ludziom.

3 Stanisław Skorupka, Słownik frazeologiczny języka polskiego, t. 2 (Warszawa: Wiedza Powszechna, 1987), 151. 
Nasuwa się zatem pytanie, czy dla dzisiejszego człowieka, szczególnie chrześcijanina, wezwanie do służby drugiemu i innym jest jedynie sformułowaniem o charakterze symbolicznym i teologicznym, które nie ma większego związku z codziennym życiem, czy przeciwnie - odbierane w kontekście rzeczywistości wiary zaczyna do czegoś zobowiązywać, staje się konkretne, praktyczne, uświadamia otrzymane powołanie.

Wychowawcze przygotowanie do odkrywania sensu życia osobowego i chrześcijańskiego opartego na służbie jest dziś ogromnym wyzwaniem. Jeśli służba jako postawa i zadanie ma się stać dla wychowanków ważną wartością, musi być zrozumiana, doświadczona, przeżyta i praktykowana. Wydaje się, że w świetle współczesnych tendencji kulturowych samo zrozumienie znaczenia służby jako wartości wymaga przede wszystkim wiarygodnego wyjaśnienia i uzasadnienia. Dotyczy to także chrześcijan. Radykalizm chrześcijańskiego myślenia o służbie i jej nierozerwalnym związku z życiem chrześcijańskim warunkuje bowiem świadomość bycia człowiekiem wiary, określa tożsamość chrześcijanina. Kształcenie tej świadomości jest jednym z głównych zadań wychowania chrześcijańskiego. W Deklaracji o wychowaniu chrześcijańskim Soboru Watykańskiego II czytamy, że wychowanie chrześcijańskie:

zmierza nie tylko do pełnego rozwoju osoby ludzkiej (...), lecz przede wszystkim stara się o to, aby ochrzczeni poprzez stopniowe wprowadzanie w misterium zbawienia z każdym dniem byli bardziej świadomi otrzymanego daru wiary, aby uczyli się czcić Boga w Duchu i prawdzie (por. J 4, 23), zwłaszcza przez uczestnictwo w liturgii; aby stali się zdolni do prowadzenia własnego życia według nowego człowieka w sprawiedliwości i prawdziwej świętości (por. Ef 4, 13). (...). Oni to właśnie, świadomi swego powołania [podkr. K.O.], winni codziennie dawać świadectwo nadziei, która w nich jest (por. 1 P 3, 15), oraz pomagać w chrześcijańskim kształtowaniu świata, aby dzięki temu wartości naturalne włączone do pełnego zrozumienia człowieka odkupionego przez Chrystusa przyczyniały się do dobra całej społeczności

Wprowadzanie w zrozumienie miejsca służby w rozwoju osobowym i chrześcijańskim jest więc jednym z najważniejszych zadań wychowania chrześcijańskiego. Dziś nabiera ono szczególnego znaczenia. Ważną pomo-

${ }^{4}$ Sobór Watykański II, „Deklaracja o wychowaniu chrześcijańskim Gravissimum educationis", w: Sobór Watykański II. Konstytucje, Dekrety, Deklaracje (Poznań: Pallottinum, 1967), $\mathrm{nr} 2$. 
cą w jego realizacji mogą być wypowiedzi i teksty papieży końca XX i początku XXI wieku - św. Jana Pawła II i Benedykta XVI - którzy prowadzili intensywny dialog z kulturą swoich czasów, zwracając uwagę na charakterystyczne dla niej niepokojące zjawiska i wskazując bardziej lub mniej bezpośrednio kierunek pracy wychowawczej i samowychowawczej.

Spróbujmy przyjrzeć się, w jaki sposób Jan Paweł II i Benedykt XVI pomagali w zrozumieniu tej niezwykle trudnej kulturowo wartości i postawy, jaką jest służba. W tych rozważaniach wybrano teksty kierowane przez przywoływanych papieży do słuchaczy o bardzo różnym, raczej niewielkim przygotowaniu teologicznym, ponieważ właśnie ze względu na taki charakter mogą wnieść bardzo wiele we współczesne poszukiwania skutecznych dróg wychowania chrześcijańskiego.

\section{1. „Służba” w wypowiedziach i tekstach św. Jana Pawła II}

Jednym z głównych tematów podejmowanych przez papieża Jana Pawła II w czasie całego jego pontyfikatu była potrzeba przekładania wiary na kulturę. Podkreślał On, że wiara, aby była żywa, musi być „przekładana” na kulturę tworzoną przez człowieka i kształtującą go. Jeżeli nie będzie obecna w sposobie myślenia, działania, funkcjonowania, w stylu życia, wzorach zachowania i sferze materialnej, stanie się martwa, sztywna, będzie narzuconą, doktrynerską ideologią. W tym kontekście widoczne staje się, że dziś służba Bogu i ludziom nie funkcjonuje w kulturze w takim sensie, o jakim mówił Jan Paweł II. Nawet jeśli jest teoretycznie przyjmowana w myśleniu religijnym, nie przekłada się na rzeczywistość codziennego życia.

Jan Paweł II wracał do sprawy ważności służby w wielu wypowiedziach adresowanych do młodzieży, co wskazywałoby na to, iż w Jego ocenie szczególnie dla młodych ludzi idea służby może być trudna, niezrozumiała i obca. Na spotkaniu w Bombaju w 1986 roku papież wzywał młodzież: „Każdy z was powołany jest do pełnienia konkretnej służby, wszyscy zaś razem powołani jesteście do pracy nad przemianą świata"s. Wskazując konkretne obszary realizowania tego wezwania, zaznaczył, że potrzebne w tym procesie jest „,szukanie w Maryi, matce Jezusa, przykładu życia poświęconego ofiarnej służbie - życia otwartego na Boga i przepojonego żarliwym

5 Jan Paweł II, „Przemówienie w czasie spotkania z młodzieżą w Bombaju 10.02. 1986”, w: Podręcznik Pokolenia JP II. Ojcowskie słowo do młodych świata, Polski i Lednicy (Poznań: Duszpasterstwo Akademickie Dominikanów, 2008), 237. 
pragnieniem służenia ludziom"6. Przytoczmy jeszcze jeden fragment tego przemówienia: „Należeć do Chrystusa i zachowywać Jego przykazanie miłości, znaczy podjąć wezwanie do służby bliźniemu, wnosić własny wkład w życie społeczeństwa, pracować dla dobra ojczyzny i całego świata"7.

Jeszcze mocniej i wyraźniej o istocie służby mówił papież w 1989 roku na spotkaniu z młodymi w Santiago de Compostela: „Wspólnota uczniów Chrystusa to nie agencja wolontariatu i pomocy społecznej. Taka służba ograniczałaby się do horyzontu «ducha tego świata». Nie! Chodzi tu o coś znacznie większego. Radykalizm, jakość i przeznaczenie służby, do której wszyscy jesteśmy wezwani, wchodzą w zakres tajemnicy Odkupienia człowieka"8. Z perspektywy wiary służba nie jest więc jedynie świadczoną bezinteresownie pomocą, choć ta zawsze zasługuje na pozytywną ocenę. W służbie wynikającej z wiary chodzi o gotowość otwarcia swojego życia na Boga, tym samym budowanie całego życia na gotowości do służby Bogu, ludziom, wspólnocie Kościoła. W takim ujęciu każdy jest powołany do pełnienia konkretnej służby. Mamy tu do czynienia z wyraźnym odejściem od podziału na służbę jako postawę i aktywność specjalną, wyjątkową, w odbiorze społecznym „wysoką", kojarzoną z wybranymi zawodami i rolami, wartą specjalnego szacunku, i tę codzienną, dotyczącą każdego, jako służenie innym w różnych, nawet drobnych sprawach. Służba widziana w świetle wiary jest realizacją przykazania miłości, podejmowaną dlatego, że człowiek chce należeć do Chrystusa. W takim rozumieniu, pełniąc codzienną służbę, wnosi się ważny wkład w życie społeczeństwa i świata, bo przekształca się świat razem z Chrystusem. W świetle wiary każdy jest powołany do pełnienia służby, w której ma naśladować Chrystusa w służbie ofiarnej, która tworzy jego życie.

U Jana Pawła II znajdujemy zdecydowane stwierdzenia: służba jest miarą i „kryterium wielkości człowieka”. W innym miejscu papież mówi, że służba jest „wymiarem wolności człowieka"10, bo człowiek jest wolny wtedy, kiedy dobrowolnie podejmuje działanie, które w swej istocie jest

6 Tamże, 238.

7 Tamże, 236.

8 Jan Paweł II, „Homilia podczas mszy św. na zakończenie IV Światowego Dnia Młodzieży. Santiago de Compostela. 20.08.1989”, w: Podręcznik Pokolenia JP II. Ojcowskie słowo do młodych świata, Polski i Lednicy (Poznań: Duszpasterstwo Akademickie Dominikanów, 2008), 450.

\footnotetext{
9 Tamże, 449.

${ }_{10}$ Tamże, 451.
} 
działaniem z Chrystusem, według zamysłu Boga. Służba jest miarą miłości Boga i człowieka, nie można więc mówić o miłości bez służby.

Jan Paweł II dużą część swojego nauczania poświęcił na przybliżanie ludziom istoty ich tożsamości. Pragną, żeby zrozumieli, kim są jako osoby i co znaczy być człowiekiem, wreszcie - co znaczy być chrześcijaninem. Przypominał, że każdy człowiek jest osobą, jest obdarzony godnością ludzką. Swoje życie powinien orientować na wartości wyższe - prawdę, dobro, piękno, dążyć do świętości. Spełnia się jedynie jako dobrowolny, bezinteresowny dar z siebie. Dar, który ma służyć drugiemu jako osobie ludzkiej, jego rozwojowi osobowemu, tak by mógł on funkcjonować w sposób rozumny, wolny, odpowiedzialny, by mógł dążyć do wartości wyższych, żeby był szanowany i szanował siebie, wreszcie żeby doświadczał miłości i świadczył miłość.

Jeśli przyjmiemy, że służba - w myśl nauczania Jana Pawła II - jest byciem darem, to nie można spełnić siebie bez przyjęcia postawy służby. Jan Paweł II zwracał uwagę, że warunkiem osobowego rozwoju człowieka jest posiadanie umiejętności przyjmowania postaw osobowych. Do postaw tych zaliczał - oprócz postaw szacunku i miłości, troski i odpowiedzialności właśnie postawę służby ${ }^{11}$. Podkreślał, że przyjmowanie tych postaw wymaga przede wszystkim bezinteresowności. W adhortacji apostolskiej Familiaris Consortio mówi o „prawie bezinteresowności”: „We wzajemnych stosunkach członkowie wspólnoty rodzinnej są inspirowani i kierują się «prawem bezinteresowności», które szanując i umacniając we wszystkich i w każdym godność osobistą jako jedyną rację wartości, przybiera postać serdecznego otwarcia się, spotkania i dialogu, bezinteresownej gotowości służenia, wielkodusznej służby i głębokiej solidarności" ${ }^{\prime 2}$. Uświadamiał, że każdy człowiek jest obdarzony przez Boga jakimiś szczególnymi darami i jest zobowiązany, by ich szukać, odkrywać, a potem zaangażować w służbę innym. Młodzi na wspomnianym potkaniu w Composteli usłyszeli: „Trzeba rozeznać dobrze, czym zostałeś obdarzony przez Boga w Chrystusie. Trzeba dobrze rozeznać dar otrzymany, aby umieć nim obdarzać innych. Aby przyczyniać się do wspólnego dobra"13.

11 Jan Paweł II, Encyklika Evangelium vitae (Watykan, 1995).

12 Jan Paweł II, „Adhortacja apostolska Familiaris Consortio o zadaniach rodziny chrześcijańskiej w świecie współczesnym", w: Adhortacje Apostolskie Ojca świętego Jana Pawła II, t. I: 1979-1995 (Kraków: Znak, 2006), nr 43.

13 Jan Paweł II, „Homilia”, 451. 
Bycie bezinteresownym darem obejmuje służbę drugiemu w relacji ja-ty, ale także w relacjach, które budują wspólnotę, będącą nie tylko zintegrowaną grupą, ale całością osobową. Dziś pojęcie wspólnoty jest używane w różnych kontekstach i celach, jednakże jego źródłowe znaczenie jest znaczeniem chrześcijańskim i osobowym (wspólnota podziela te same wartości, a wszyscy respektują wartości osobowe każdego z jej członków, traktując rozwój osobowy wszystkich jako dobro wspólne). Wspólnota respektuje i szanuje każdą osobę, bo oparta jest na byciu wzajemnym bezinteresownym darem z siebie i zakłada, że jeśli ludzie chcą być dla innych tak rozumianym darem, są gotowi im służyć.

$\mathrm{Z}$ przyjęciem postawy służby wiąże się szereg poważnych przemian w człowieku. Przede wszystkim postawa ta pozwala zwalczyć powszechną wśród ludzi pokusę panowania nad innymi, co, jak podkreślał często papież, nie jest łatwe. Wymaga bliskiej więzi z Chrystusem: „Kto żywi się ciałem Chrystusa, znajduje siły, by wykonać braterski gest. Między Chrystusem a uczniem kształtuje się w ten sposób więź bliskości i jedności, która głęboko przemienia człowieka, aby uczynić zeń sługę. Jedynie codzienna więź Chrystusa z uczniem może uczynić zeń sługę"14. Warto zauważyć, że w tym kontekście dystans współczesnej kultury wobec służby oparty jest na trafnej intuicji, że wiąże się ona z ogromnym trudem. To, co człowiek jest w stanie sam z siebie wykrzesać, podejmując działanie dla dobra innych, jest najczęściej albo dobrowolną, ale okazjonalną pomocą, czyli wolontariatem, albo na poziomie służenia wyższym wartościom - heroizmem, który zasługuje na szacunek i uznanie.

Gdy kardynał Karol Wojtyła, będąc jednym z Ojców Soboru Watykańskiego II, relacjonował w Krakowie jego prace, wyjaśniał między innymi, że Sobór stara się zapisać w swoich dokumentach, co oznacza bycie człowiekiem wiary. W tym kontekście zwracał uwagę, że w dokumentach soborowych mówi się o uczestniczeniu chrześcijanina w potrójnej misji Chrystusa: prorockiej, kapłańskiej i królewskiej. Misja królewska jest misją wejścia w służbę, a więc bycia dobrowolnym darem dla drugiego człowieka i dla wspólnoty po to, żeby inni mogli się rozwijać w sposób osobowy.

Inny fragment refleksji św. Jana Pawła II z przytaczanego wyżej przemówienia w Composteli pomaga dostrzec, że dla papieża istnieje ścisły związek przyjmowania postawy służby ze świadomością własnej tożsamości: „Jeśli

14 Jan Paweł II, „Tekst do młodzieży przekazany w czasie spotkania w Paryżu, 21.08.1997”, w: Podręcznik Pokolenia JP II. Ojcowskie stowo do młodych świata, Polski i Lednicy (Poznań: Duszpasterstwo Akademickie Dominikanów, 2008), 590. 
naprawdę chcecie służyć swoim braciom, pozwólcie, by Chrystus królował w waszych sercach, by wam pomagał coraz lepiej rozumieć samych siebie i panować nad sobą"15. Jan Paweł II uważał, że jednym z największych problemów współczesnego człowieka jest zaburzona tożsamość; nie wie on kim jest, nie wie, że jest osobą ludzką, i jako osoba ma takie, a nie inne atrybuty, możliwości i zadania, nie wie, że przysługuje mu bezwarunkowa godność i jako osoba zasługuje na szacunek. Nie wie więc też, że postawa służby, tak ważna w życiu każdego człowieka, wymaga świadomej więzi z Chrystusem.

Warto wspomnieć, że tę prawdę potwierdza psychologia, która przyjmuje jako jeden ze wskaźników dojrzałości poziom allocentryzmu, co wskazywałoby na to, że człowiek nie posiada naturalnych skłonności do postrzegania potrzeb innych ludzi. Przeciwnie - łatwiej, w sposób naturalny przyjmuje postawę egocentryczną, kierując się głównie własnymi potrzebami, nie interesując się potrzebami innych. Także $\mathrm{z}$ tej perspektywy trzeba więc zauważyć, że przyjmowanie postawy i pełnienie radykalnie rozumianej służby jest dla człowieka bardzo trudne; również dla człowieka wierzącego, szczególnie jeśli nie rozumie jej sensu.

Częste współcześnie rozchwianie tożsamości wytworzyło potrzebę specjalistów oferujących pomoc w rozwoju osobistym, w poszukiwaniach duchowych $^{16}$ i osiąganiu osobistego sukcesu. Pomoc ta jest ważnym wsparciem dla wielu ludzi, ale nie daje odpowiedzi na pytania, po co i w jakim sensie warto bądź należy się rozwijać, pracować nad własną duchowością. Uzyskanie poczucia komfortu psychicznego i realizacji własnego potencjału jest odpowiedzią zastępczą wobec braku odpowiedzi na pytania o sens życia

15 Jan Paweł II, „Przemówienie w czasie spotkania z młodzieżą w Santiago de Compostela. 20.08.1989", w: Podręcznik Pokolenia JP II. Ojcowskie słowo do młodych świata, Polski i Lednicy (Poznań: Duszpasterstwo Akademickie Dominikanów, 2008), 451.

16 Por. teksty o współczesnej duchowości i „nowej duchowości” m.in.: Janusz Mariański, „Nowa duchowość - alternatywa czy dopełnienie religijności?”, w: Religijność i duchowość. Dawne i nowe formy, red. Maria Libiszowska-Żółtowska, Stella Grotowska (Kraków: Zakład Wydawniczy Nomos, 2010), 19-34; Andrzej Kasperek, Wolność spod znaku undergroundu. Duchowość (po)nowoczesna w perspektywie hermeneutyki kultury i socjologii religii (Kraków: Zakład Wydawniczy Nomos, 2012); Zbigniew Pasek, „Od religijności do duchowości. Przyczynek do przemian kultury współczesnej”, w: Filozoficzne i kulturoznawcze rozważania o duchowości i komunikowaniu, red. Ignacy Stanisław Fiut (Kraków: Uczelniane Wydawnictwa Naukowo-Dydaktyczne AGH, 2008), 13-26; Duchowy rozwój człowieka - fazy życia, osobowość, wiara, religijność. Stadialne koncepcje rozwoju w ciagu życia, red. Paweł Socha (Kraków: Wydawnictwo Uniwersytetu Jagiellońskiego, 2000); Maria Znaniecka, Kategoria duchowości i jej wybrane parafrazy w pedagogice (Gdańsk: Wydawnictwo Uniwersytetu Gdańskiego, 2016). 
i rozwoju. Potencjał każdego człowieka jest inny i może być angażowany w bardzo różne cele. Trudno więc byłoby stwierdzić, co należałoby i co warto byłoby w danym człowieku rozwijać, w czym mu pomóc, by poczuł się spełniony.

W świetle myślenia osobowego i wiary chrześcijańskiej ostatecznym spełnieniem siebie jest dla człowieka bycie bezinteresownym darem dla drugiego (w sensie osobowym). Każdy ochrzczony przez sam fakt chrztu niejako wszedł w służbę Bogu i ludziom. Jest to trudna rzeczywistość i trzeba dobrze ją zrozumieć, żeby praktycznie zacząć w niej żyć: „Służba jest drogą do szczęścia i świętości; nasze życie staje się dzięki niej czynnym wyrazem miłości do Boga i do naszych braci. (...) Niech miłość i służba staną się podstawowymi zasadami waszego życia! Składając siebie w ofierze odkryjecie, co wam zostało ofiarowane, i sami z kolei otrzymacie dar Boży"17.

Dla Jana Pawła II służba jest wezwaniem do bycia prawdziwym chrześcijaninem. Nie można być chrześcijaninem bez świadomego wejścia w powołanie służby, gdyż chrześcijaństwo nie jest „dodatkiem do życia” czy jednym z możliwych wyborów życiowych, ale obecnością wewnątrz rzeczywistości Bożej. Przez fakt chrztu człowiek zaczyna uczestniczyć w tej rzeczywistości, jest zaproszony do tego, aby naśladować Chrystusa i współpracować z Nim w przekształcaniu świata, tym samym służba, będąc jednocześnie współdziałaniem z Chrystusem, staje się najważniejszym zadaniem człowieka.

W refleksji św. Jana Pawła II o służbie zawarta jest odpowiedź na pytanie o cel i sens rozwoju osobistego. Trzeba poznawać świat, starać się go zrozumieć, odnaleźć w swojej sytuacji życiowej różne możliwe formy służby i odkryć swoje talenty (czyli rozwijać się), żeby tym wszystkim, co się odkryje i wydoskonali, służyć ludziom. Z kolei podjęta już służba ujawnia i wzmacnia kolejne, często nierozpoznane wcześniej możliwości. Rozwój i służba w tym ujęciu są w pełni zintegrowane, wzajemnie się wzmacniają i warunkują. Streszczając nauczanie Jana Pawła II o powołaniu do służby, można powiedzieć: będąc chrześcijanami, wchodzimy w rzeczywistość Bożą, zakorzeniamy się w Chrystusie poprzez chrzest, co powinno zaowocować poszukiwaniem swojego powołania do służby, związanego z tym miejsca w świecie, odkrywaniem w sobie możliwości osobowościowych i rozwijanie ich w możliwie pozytywnych kierunkach, które mogą być przydatne w służbie, do jakiej jesteśmy lub będziemy posłani.

17 Jan Paweł II, „Tekst do młodzieży”, 588. 


\section{Służba w życiu czlowieka wierzącego - według Benedykta XVI}

Niepokój, że chrześcijanie nie dostrzegają służby jako swojego powołania wyrażał także Benedykt XVI i także On wyjaśniał istotę i miejsce służby w chrześcijaństwie. Jeszcze jako Joseph Ratzinger rozpoczął dialog z człowiekiem współczesnym, odpowiadając na jego milcząco przeżywane pytania i wątpliwości. Jedno z kazań Ratzingera, wygłoszonych przez Niego w katedrze w Münster w 1964 roku, a zaakceptowanych po latach do publikacji już przez papieża Benedykta XVI (w konsekwencji autoryzowanych podwójnie: jako teksty Ratzingera i Benedykta XVI), zostało zatytułowane: Wiara jako stużba. Cały ten tekst jest wnikliwą analizą sposobu rozumienia fundamentalnej dla chrześcijaństwa relacji wiary i służby. Możemy w nim przeczytać:

W fakcie, że ktoś staje się chrześcijaninem, nie chodzi o zapewnienie sobie indywidualnej premii, nie jest to prywatna rezerwacja biletu do nieba, dzięki której moglibyśmy patrzeć na innych i mówić: „,mam coś czego nie mają inni, mam zbawienie, którego inni nie mają". Bycie chrześcijaninem nie jest czymś, co otrzymujemy tylko dla siebie po to, aby móc się odgrodzić od innych, którzy nie otrzymali tego daru. Nie. W pewnym sensie człowiek nie staje się chrześcijaninem dla siebie, lecz dla całości, dla innych, dla wszystkich. Ruch stawania się chrześcijaninem, który rozpoczyna się wraz z chrztem, i który obejmuje całe nasze życie, oznacza gotowość do służby, której Bóg oczekuje od nas w dziejach. Oczywiście nie zawsze możemy wiedzieć, dlaczego w danym momencie moja służba ma wyglądać w taki właśnie sposób. Jest to sprzeczne z tajemnicą historii, która utkana jest z niemożliwych do przeniknięcia wolności człowieka i wolności Boga. Powinna nam wystarczyć płynąca z wiary wiedza, że stając się chrześcijanami, stajemy w służbie całości. Stanie się chrześcijaninem nie oznacza zatem zdobycia czegoś wyłącznie dla siebie, przeciwnie, oznacza porzucenie egoizmu, który zna tylko siebie i któremu chodzi tylko o siebie, i wejście w nową formę egzystencji kogoś, kto żyje wspólnotą ${ }^{18}$.

Znajdujemy więc i tu myśl, że wejście w wiarę oznacza wejście w służbę nie w wyniku jej doraźnego wyboru, ale w wyniku samego faktu bycia

18 Joseph Ratzinger - Benedykt XVI, O sensie bycia chrześcijaninem, przeł. Jarosław Merecki (Kraków Salwator, 2006), 53-54. 
chrześcijaninem. Benedykt XVI w tym znamiennie zatytułowanym tekście przedstawia powody, dla których, jego zdaniem, wielu ludzi uważa dziś, że służba Bogu jest „nieopłacalna”, niewarta trudu. Ludzie ci wiedząc, że zbawienie jest perspektywą i szansą otwartą przez Chrystusa dla wszystkich, którzy chcą osiągnąć zbawienie, zastanawiają się, dlaczego właśnie oni mają podejmować trud codziennej służby Bogu i ludziom, skoro tak wielu innych chrześcijan tego nie robi, a także otrzymało obietnicę Zbawienia. Tak postrzeganą „nieopłacalność” trudnej codziennej służby wzmacnia dodatkowo brak spektakularnych efektów służby chrześcijan w skali świata i jego potrzeb. Według Ratzingera - Benedykta XVI ludzi tak myślących można nazwać „robotnikami pierwszej godziny”. Byliby gotowi wysilać się, służąc Bogu i ludziom, gdyby okazało się, że ich służba zostanie wynagrodzona, a postawa innych, mniej zaangażowanych - nie; gdyby wiedzieli, że inni ponieśli lub poniosą negatywne konsekwencje uchylania się od służby.

Tymczasem, jak zaznacza Autor tekstu, rzeczywistość Boża jest inna. I tu Ratzinger - Benedykt XVI zwraca uwagę na zjawisko, które, jego zdaniem, leży u podstaw kryzysu dzisiejszej kultury. Tak jak Jan Paweł II podkreślał przede wszystkim związek tego kryzysu z kryzysem tożsamości człowieka i tożsamości chrześcijanina, Benedykt XVI zatrzymuje się na innym czynniku i za główny powód dzisiejszego kryzysu kultury uznaje kryzys wiary. Zdaniem papieża, często jest ona nie tylko słaba, ale płytka, nie do końca uświadamiana i rozumiana. Trzeba więc powrócić do poznania i pogłębiania wiary, co pozwoli myśleć między innymi o służbie w kategoriach rzeczywistości Bożej, a nie tylko ludzkiej. Zgodnie z tym myśleniem to nie człowiek ma ostatecznie decydować, czy służba jest zgodna z jego planami, czy jest dla niego odpowiednia, czy sobie poradzi itd. Jego zadaniem jest z pełnym zaufaniem i w sposób wolny podjąć służbę, do której zostaje powołany i zaangażować w nią wszystkie swoje dary-talenty.

Benedykt XVI powtarzał wielokrotnie, że świadomość i tożsamość chrześcijan musi być oparta na poprawnym rozumieniu, a potem przyjęciu miłości i prawdy, które są odpowiedzią na dwa charakterystyczne procesy występujące w dzisiejszej kulturze - rezygnację z głębiej pojmowanej miłości i zanegowanie prawdy. Udział chrześcijanina w świecie musi się opierać na prawdzie odkrywanej i postrzeganej w miłości. Trzeba więc wrócić do poszukiwania prawdy o człowieku, o świecie, o Bogu, o ludziach jako dzieciach Bożych zaproszonych do służby przemieniającej świat. Trzeba tę prawdę przyjąć, i to przyjąć w miłości. Jednym z ważniejszych tekstów papieża Benedykta XVI jest jego pierwsza encyklika Deus caritas est. Czytamy w niej: „Jedynie moja gotowość do wyjścia naprzeciw bliźniemu, do oka- 
zania mu miłości, czyni mnie wrażliwym również na Boga. Jedynie służba bliźniemu otwiera mi oczy na to, co Bóg czyni dla mnie i na to, jak mnie kocha"19. Jak wyjaśniał Benedykt XVI, dopiero o kimś, kto świadomie, z miłością podejmuje służbę w ramach swojego powołania życiowego, można powiedzieć, że jest chrześcijaninem. Trzeba dobrze rozumieć, czym jest miłość chrześcijańska. „Kochać po chrześcijańsku oznacza próbę pójścia tą drogą: kochać nie tylko tego, kto ma nam coś do zaoferowania, lub tego, od kogo oczekujemy jakiejś korzyści. Kochać po chrześcijańsku (...) oznacza być dobrym dla tego, kto potrzebuje naszej dobroci, nawet jeśli nie budzi on naszej sympatii”" ${ }^{20}$. Kryteria, które pozwalają ocenić wiarygodność postawy chrześcijańskiej, to miłość, miłość ofiarna, która wyraża się w służbie, miłość do Boga i służba Bogu w człowieku. Dzisiejsza kultura nie znajduje u chrześcijan takiej postawy, dlatego nie ma motywacji, by zbliżać się do Boga.

Benedykt XVI zwraca uwagę, że rozumienie Boga jako kochającego Ojca wymaga tego, żeby człowiek był gotowy podjąć służbę dla drugiego, bowiem to służba coraz bardziej otwiera na miłość Boga i człowieka. Papież wyjaśnia, że pełniona przez chrześcijan służba jest potrzebna, by Bóg mógł przychodzić do ludzi. „Tajemnica Izraela i tajemnica Kościoła uczą nas tego samego; że Bóg chce przyjść do ludzi tylko przez ludzi”21. Potwierdza to cała historia przymierza Boga z ludźmi. Człowiek żyje we wspólnocie i dzięki wspólnocie. Bóg stale stawia człowieka w sytuacjach wspólnotowych, bowiem ludzie mają być dla siebie wzajemnie darem i wzajemnie pomagać sobie w drodze do zbawienia, prowadzić siebie nawzajem do zbawienia (Jan Paweł II także często powtarzał, jak wspomina jego wychowanek i przyjaciel Stanisław Grygiel, że jeśli ktoś rzeczywiście kocha prawdziwą miłością, to pośredniczy w przekazywaniu piękna i miłości Bożej²2).

Ostatnie z kazań cytowanego zbioru, zatytułowane Miłość, poświęcone jest wyjaśnieniu istoty chrześcijańskiej miłości oraz jej związku ze służbą. Ratzinger używa w tym rozważaniu ciekawego określenia: „,prawo nadmiaru”. Objaśnia je następująco: służba jest wyrazem miłości; służba polegająca na świadczeniu miłości oznacza obdarzanie drugiego miłością według jego potrzeb, ponad racjonalnie uzasadnione wymogi. To może rodzić w obdarowującym wątpliwość i lęk, że nie ma w sobie aż takiej miłości, by wystarczy-

19 Benedykt XVI, Encyklika Deus caritas est (Watykan, 2005), nr 18.

20 Ratzinger - Benedykt XVI, O sensie, 70.

${ }^{21}$ Tamże, 55.

22 Stanisław Grygiel, Na ścieżkach prawdy. Rozmawiając z Janem Pawłem II (Poznań: Flos Karmeli, 2013). 
ła do tak hojnego obdarzania innych. Powody mogą być różne - złe doświadczenia osobiste, trudne usposobienie czy wreszcie brak wiary w możliwość bycia kochanym. Ratzinger - Benedykt XVI przekonuje, że nie trzeba się tym martwić. Pismo Święte w wielu miejscach pokazuje, że Chrystus dając, zawsze jest nadspodziewanie hojny, hojny ponad miarę, ponad racjonalne potrzeby (żeby przywołać tylko scenę rozmnożenia chleba). Zawierzenie Chrystusowi przynosi zawsze łaskę w nadmiarze. Zdaniem Benedykta XVI, w dzisiejszej kulturze wszyscy cierpimy na deficyt miłości. Jednakże nie grozi nam nigdy rzeczywisty deficyt miłości. Jeśli otworzymy się na powołanie do służby, wejdziemy w nie z głębokim zawierzeniem i poczuciem bliskości z Chrystusem, gotowością współdziałania z Nim, zacznie działać Chrystusowe ,prawo nadmiaru”. To czego nam brakuje, do czego nie jesteśmy zdolni, wypełni Chrystus według swojego prawa nadmiaru i okaże się, że Jego miłości wystarcza, żeby dopełnić nasz „deficyt” miłości. W przywoływanym tekście czytamy:

Jezus chce nam wskazać nie tylko na sąd i przebaczenie, które sprawiłyby, że wszelkie ludzkie działania stałyby się obojętne, lecz chce nam również dać wskazówkę, która dotyczy naszego życia; chce nas skierować ku temu „więcej”, ku temu „nadmiarowi” i tej hojności, które nie oznaczają, że nagle staniemy się bezbłędni i doskonali, lecz sprawią, że zaczniemy poszukiwać postawy człowieka kochającego, który nie kalkuluje, lecz po prostu kocha. (...) Bóg sam żyje i działa zgodnie z prawem nadmiaru, tej miłości, która nie potrafi dać mniej niż siebie samą. Chrześcijaninem jest ten, kto żyje miłością. Taka jest najprostsza odpowiedź na pytanie o istotę chrześcijaństwa ${ }^{23}$.

\section{Wnioski dla wychowania}

W tekstach obydwu cytowanych tu papieży uderza sposób przekazywania bardzo trudnej dla współczesnego człowieka prawdy o istocie służby widzianej w świetle wiary. Dla każdego, kto chce podjąć trud wychowania chrześcijańskiego (a ono samo jest szczególną służbą), przedstawione tu przykłady mogą być ważną wskazówką. Ani Jan Paweł II, ani Benedykt XVI nie starają się złagodzić radykalizmu przekazywanych treści. Nie pokazują służby jako postawy wymagającej jedynie wrażliwości i dobrej woli. Przeciwnie, nie ukrywają, że jest to postawa trudna, wymagająca prawdziwej

${ }^{23}$ Ratzinger - Benedykt XVI, O sensie, 82. 
wiary, zrozumienia powołania chrześcijańskiego, a przede wszystkim oparcia się na bliskiej więzi z Chrystusem. Jednakże forma przekazu tych treści jest stosunkowo prosta, przystępna, odwołująca się do doświadczeń współczesnego człowieka, do zakładanych jego wątpliwości i pytań, traktująca ze zrozumieniem i szacunkiem potrzebę wyjaśniania mu od podstaw istoty bycia chrześcijaninem. Mamy tu do czynienia nie tyle z wykładem, co raczej formą nawiązującą do dialogu biorącego pod uwagę sposób myślenia i trudności odbiorców.

Cytowane teksty stanowią praktyczną realizację programu, o którym mówił Karol Wojtyła, kiedy objaśniając prace Soboru podkreślał, że w dokumentach soborowych chodzi głównie o wskazanie dróg wzbogacania wiary współczesnych ludzi, dróg uwzględniających istotne zmiany w kulturze, w jakiej przyszło im żyć. Musi to być wzbogacanie, które byłoby realizowane w wymiarze podmiotowym, egzystencjalnym, poprzez ksztaltowanie świadomości wiary oraz ksztaltowanie postaw, które ją wyrażają. Obie te sfery - świadomości i postaw - wzajemnie się warunkują i obydwie są niezbędne w dążeniu do wiary i jej pogłębiania ${ }^{24}$.

Znajdujemy tu zarówno przekaz wiedzy o sensie chrześcijańskiej służby, jak i dzielenie się żarliwym przekonaniem o jej niezwykłej wartości dla każdego człowieka, co wpływa i na świadomość, i na postawę służby. Uczenie wartości i kształtowanie służących im postaw wymagają ich poznania, doświadczenia i przeżycia, zrozumienia, osobistego sprawdzenia i uznania za swoje. Niezbędne na tej drodze są wiarygodne przykłady ludzi, których życie można obserwować na przestrzeni dłuższego czasu. W przypadku służby powszechnie na świecie znane i cenione biografie tak Jana Pawła II dziś już świętego, jak Benedykta XVI potwierdzają możliwość codziennego jej podejmowania i pełnienia niezależnie od warunków. Obaj ci papieże papieże początków nowego, trzeciego tysiąclecia - mogą być przykładami służby Bogu, człowiekowi, prawdzie i Kościołowi.

Służba traktowana jako droga osobowego spełniania siebie i powołanie chrześcijanina, otwierając na drugiego człowieka, może stanowić równocześnie inspirację do ogólniejszego namysłu nad wartością służby - działania i postawy - dla indywidualnego rozwoju, dla wszelkich relacji międzyludzkich i jakości życia społecznego. Rosnące zainteresowanie wolontariatem wskazuje na zmęczenie współczesnej kultury programami zorientowanymi na indywidualny rozwój, zamykający jednostkę w egoistycznej samoreali-

${ }^{24}$ Karol Wojtyła, U podstaw odnowy. Studium o realizacji Vaticanum II (Kraków: Wydawnictwo Unum, 2003). 
zacji i wywołujący społeczną izolację, anonimowość, wzajemną obojętność, a także instrumentalne uprzedmiotawianie jednostek i grup. Odrzucenie wartości służby jako gotowości służenia drugiemu człowiekowi wydaje się także istotnym powodem kryzysu współczesnej rodziny.

Z tej perspektywy wychowanie chrześcijańskie, kształtując świadomość wartości służby, może wnieść znaczący wkład w szeroko rozumianą działalność wychowawczą, prowadząc do budowania kultury bardziej wrażliwej na potrzeby innych.

\section{The Place of Service in Christian Education - in the Light of the Reflections of John Paul II and Benedict XVI (Summary)}

The article deals with the Christian understanding and educational approach to the category of service. The author starts with the meaning of the notion of service and the place of this category in contemporary culture. She treats the "service" as the value of a particular action and as an attitude (of service) in the sense of an informed willingness to voluntarily undertake it. She assumes that today's culture is distancing itself from the service, reserving that category only for special activities, requiring special skills, above average behaviour, selfless effort and responsibility. Only service understood this way deserves recognition and social respect. The subject of the author's reflections is service in the sense of the Christian attitude, binding on every Christian. Its awareness and implementation in the unfavourable for service cultural environment poses a serious challenge to Christian education. The approach to bringing the personal and Christian sense of service requires serious consideration, the search for credible arguments and the form of message. The author points to the writings of John Paul II and Benedict XVI on the Christian thinking of service as an important aid in this task.

Keywords: service; value of the service; service attitude; Christian education.

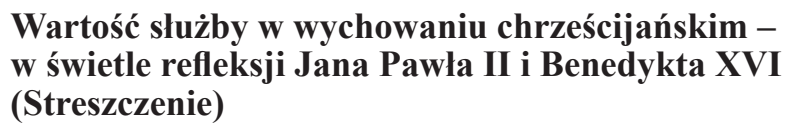

Artykuł dotyczy chrześcijańskiego rozumienia i wychowawczego przybliżania kategorii „służby”. Autorka wychodzi od znaczenia pojęcia „służby” i miejsca 
tej kategorii w kulturze współczesnej. „Służbę” traktuje jako wartość konkretnego działania oraz jako postawę (służby) w sensie świadomej gotowości do jej dobrowolnego podejmowania. Przyjmuje, że dzisiejsza kultura dystansuje się od służby, rezerwując te kategorię wyłącznie dla działań specjalnych, wymagających szczególnych umiejętności, ponadprzeciętnych zachowań, bezinteresownego w dużym stopniu wysiłku i odpowiedzialności. Tylko tak rozumiana służba zasługuje na uznanie i społeczny szacunek. Przedmiotem rozważań Autorki jest służba w rozumieniu postawy chrześcijańskiej, obowiązującej każdego chrześcijanina. Jej uświadamianie i wprowadzanie w życie w nieprzychylnym służbie otoczeniu kulturowym stanowi poważne wyzwanie dla wychowania chrześcijańskiego. Sposób przybliżania osobowego i chrześcijańskiego sensu służby wymaga poważnego namysłu, poszukiwania wiarygodnych argumentów i form przekazu. Autorka jako ważną pomoc w realizacji tego zadania wskazuje teksty Jana Pawła II i Benedykta XVI dotyczące chrześcijańskiego myślenia o służbie.

Słowa kluczowe: służba; wartość służby; postawa służby; wychowanie chrześcijańskie.

\section{Bibliografia}

Benedykt XVI. Encyklika Deus caritas est. Watykan 2005.

Duchowy rozwój człowieka - fazy życia, osobowość, wiara, religijność. Stadialne koncepcje rozwoju w ciagu życia, red. Paweł Socha. Kraków: Wydawnictwo Uniwersytetu Jagiellońskiego, 2000.

Grygiel, Stanisław. Na ścieżkach prawdy. Rozmawiając z Janem Pawłem II. Poznań: Flos Karmeli, 2013.

Heska-Kwaśniewicz, Krystyna. Braterstwo i stużba. Rzecz o pisarstwie Aleksandra Kamińskiego. Katowice: Wydawnictwo Uniwersytetu Śląskiego, 1998.

Jan Paweł II. „Adhortacja apostolska Familiaris Consortio o zadaniach rodziny chrześcijańskiej w świecie współczesnym". W: Adhortacje Apostolskie Ojca świętego Jana Pawła II, t. I: 1979-1995. Kraków: Znak, 2006.

Jan Paweł II. Encyklika Evangelium vitae. Watykan 1995.

Jan Paweł II. Podręcznik Pokolenia JP II. Ojcowskie stowo do młodych świata, Polski i Lednicy. Poznań: Duszpasterstwo Akademickie Dominikanów, 2008.

Kasperek, Andrzej. Wolność spod znaku undergroundu. Duchowość (po)nowoczesna w perspektywie hermeneutyki kultury i socjologii religii. Kraków: Zakład Wydawniczy Nomos, 2012. 
Mariański, Janusz. „Nowa duchowość - alternatywa czy dopełnienie religijności?”. W: Religijność i duchowość. Dawne i nowe formy, red. Maria Libiszowska-Żółtowska, Stella Grotowska, 19-34. Kraków: Zakład Wydawniczy Nomos, 2010.

Pasek, Zbigniew. „Od religijności do duchowości. Przyczynek do przemian kultury współczesnej". W: Filozoficzne i kulturoznawcze rozważania o duchowości i komunikowaniu, red. Ignacy Stanisław Fiut, 13-26. Kraków: Uczelniane Wydawnictwa Naukowo-Dydaktyczne AGH, 2008.

Ratzinger, Joseph - Benedykt XVI. O sensie bycia chrześcijaninem. Przeł. Jarosław Merecki. Kraków: Salwator, 2006.

Skorupka, Stanisław, Halina Auderska, Zofia Łempicka. Mały słownik języka polskiego. Warszawa: PWN, 1969.

Skorupka, Stanisław. Słownik frazeologiczny języka polskiego. T. 2. Warszawa: Wiedza Powszechna, 1987.

Sobór Watykański II. „Deklaracja o wychowaniu chrześcijańskim Gravissimum educationis". W: Sobór Watykański II. Konstytucje, Dekrety, Deklaracje. Poznań: Pallottinum, 1967.

Wojtyła, Karol. U podstaw odnowy. Studium o realizacji Vaticanum II. Kraków: Wydawnictwo Unum, 2003.

Znaniecka, Maria. Kategoria duchowości i jej wybrane parafrazy w pedagogice. Gdańsk: Wydawnictwo Uniwersytetu Gdańskiego, 2016. 
